\title{
The Automatic Determination of Blood Serum Sialic Acid Levels
}

\author{
By P. Delmotte \\ From the Centre National pour la Sclérose en Plaques, Melsbroek, Belgique (Directeur: Dr. Ch. J. Ketelaer)
}

(Eingegangen am 17. März 1967)

\begin{abstract}
After a preliminary hydrolysis of the serum samples, the liberated sialic acid is determined by the thiobarbituric acid method of W ARREN adapted to the Autoanalyzer. By measuring the developed chromogen in very hot solution, the use of extraction or the addition of stabilizing agents is avoided. Sixty determinations can be run per hour and the optical densities follow a straight line well within the physiological range of concentrations.
\end{abstract}

Nach vorangegangener Hydrolyse der Serumproben wird die freigesetzte Sialinsäure (N-Acetylneuraminsäure) mit der Thiobarbituratmethode von WARREN im Autoanalyzer bestimmt. Durch Messen des entwickelten Farbstoffes in sehr heißer Lösung wird eine Extraktion und die Zugabe von Stabilisierungsmitteln umgangen. 60 Bestimmungen können in einer Stunde durchgeführt werden. Die Extinktion folgt im Bereich physiologischer Konzentrationen dem LAMBERT-BEERschen Gesetz.

As shown by the publications of many workers during recent years, the determination of sialic acid in serum seems to be of proven importance. In our own experience, its measurement offers one of the most sensitive parameters for the detection of infectious states (1). Unfortunately, the manual execution of a great number of these determinations greatly increases the work load in a busy laboratory. In this work we present a partially automated method for the determination of the serum sialic acid levels.

For the quantitative measurement of sialic acid (Nacetylneuraminic acid) in biological fluids, two interesting methods can be considered. The first one, making use of the BIAL or orcinol reagent, permits the determination of both free and bound sialic acid $(2,3,4,5)$. The coloured complex must be extracted with an organic solvent and, since the reaction is not very specific, a preliminary purification step is advisable. The second method, the thiobarbituric acid method of WARREN, has the advantage of being very specific and at the same time very sensitive $(6,7)$. Unfortunately, the thiobarbituric acid condensation can only be carried out with free sialic acid. Henceforth, in the case of serum a preliminary hydrolysis step must be performed.

Examining the different possibilities in working out this method, we adhered to two principles:

1 - the chosen method must very sensitive and sufficiently specific so as not to require a purification step; $2-$ it is essential that extraction with an organic solvent be avoided:

The WARREN method meets the first condition very well. There are two manual methods for the measurement of the final chromogen: the chromogen can be extracted with cyclohexanone, or, as described by SAIFER and Gerstenfeid, the final reaction mixture can be made less aqueous by the addition of methylcellosolve which stabilizes the coloured end product (8).

By studying the fate of the chromogen at the end of the reaction time, we observed, that as long as the mixture was held above a certain temperature, the colour was sufficiently stable to permit a normal colorimetric measurement. The Autoanalyzer equipment is ideally suited for carrying out rapid colorimetric measurements on very hot solutions.

\section{Method}

Reagents

Physiological saline.

5 and $10 \%$ Trichloracetic acid.

$0,2 \mathrm{M}$ Sodium periodate: dissolve $10.7 \mathrm{~g} . \mathrm{NaJO}_{4}$ in $75 \mathrm{ml}$. distilled water, add $157.5 \mathrm{ml}$. concentrated $\mathrm{H}_{3} \mathrm{PO}_{4}$, cool and make up to $250 \mathrm{ml}$.

$10 \%$ Sodium arsenite: dissolve $100 \mathrm{~g} . \mathrm{NaAsO}_{2}$ in about $750 \mathrm{ml}$. distilled water and add with constant stirring $21 \mathrm{ml}$. concentrated $\mathrm{H}_{2} \mathrm{SO}_{4}$. Heat the solution to about $60^{\circ} \mathrm{C}$ on a low flame. While still hot add $105 \mathrm{ml} .20 \%$ sodium hydroxide solution. After cooling make up to $1 \mathrm{l}$. and filter in to a plastic bottle.

Thiobarbituric acid reagent: dissolve $6 \mathrm{~g}$. of thiobarbituric acid (British Drug Houses) and $71.2 \mathrm{~g}$. anhydrous sodium sulphate in about $900 \mathrm{ml}$. distilled water. After complete solution let stand for 24 hours, adjust to $1 l$. and filter.

Stock standard sialic acid: dissolve pure sialic acid in distilled water ( $1 \mathrm{mg}$. per $\mathrm{ml}$.).

Test standard solutions: $4,6,8,10,12$ and $14 \mathrm{ml}$. of stock standard are diluted to $100 \mathrm{ml}$. with $5 \%$ trichloracetic acid to give standard solutions corresponding to respectively $40,60,80,100,120$ and $140 \mathrm{mg}$. sialic acid per $100 \mathrm{~m} /$. of serum.

\section{Procedure}

As the thiobarbituric acid reaction can only be applied to free sialic acid, a preliminary hydrolysis step must be performed in the case of blood serum samples. This offers no majot drawback, since a great number of samples can be treated at the same time. The preparation of the serum samples can best be carried out with an automatic three-pump dilution pipet (Research Specialities Company). In one operation, lasting only a few seconds, the sample is aspirated, washed out with diluting saline, while a third pump adds the trichloracetic acid solution. Typical volumes are: $0.2 \mathrm{~m} l$ serum, $0.8 \mathrm{ml}$. saline and $1 \mathrm{ml} .10 \%$ trichloracetic acid.

After a one hour hydrolysis in a water bath at $80^{\circ} \mathrm{C}$, the tubes are quickly cooled and after a brief centrifugation, a portion of the clear supernatent is transferred to the Autoanalyzer cups. As shown in figure 1 , the proposed manifold is straightforward. Contraty to the more general usage, the sample stream is chopped with air and the first reagent is added through the capillary side arm. The distilled water for the washing cuvet of the Sampler II is replaced with a $5 \%$ solution of trichloracetic acid. There still remains much controversy as to the time taken by the periodate oxidation to reach completion. With the proposed method the optical densities obtained show a straight line relationship with concentrations up to $140 \mathrm{mg}$. per $100 \mathrm{ml}$. This implies that, under the conditions used, the oxidation goes nearly to completion or that the same percentage of sialic acid always becomes oxidised, regardless of the concentration.

After the first mixing coil, the excess periodate is reduced by the arsenite solution and between the second and third mixing coils the thiobarbituric acid is added. 


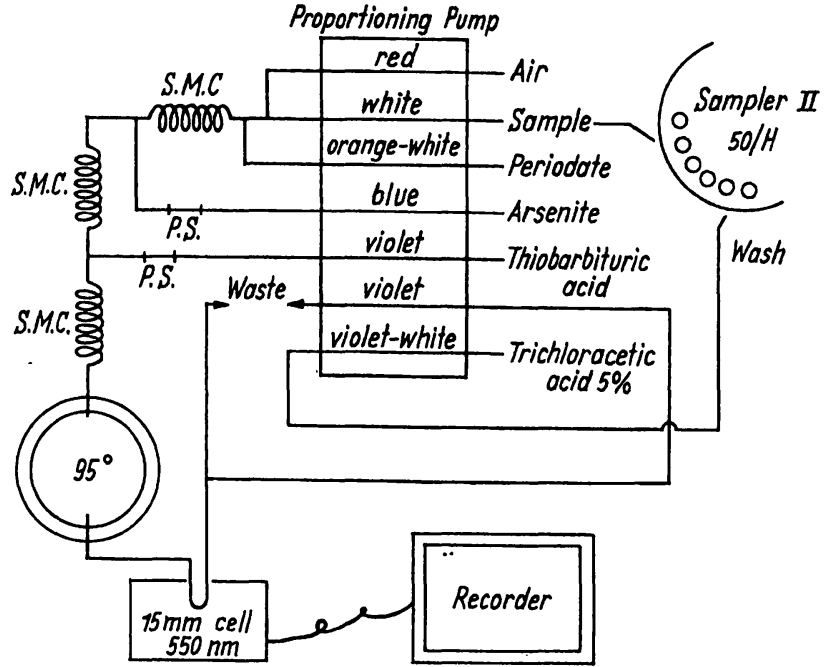

Fig. 1

Proposed manifold for for automatic sialic acid determination; S. M. C. = single mixing coil; P.S. = pulse supressor

The condensation reaction is achieved by passing the reaction mixture through the two coils of the $95^{\circ} \mathrm{Cheating}$ bath in succession. In order to avoid undue cooling, the connection between the heating bath and the colorimeter must be kept as short as possible. As the coloured end product shows a sharp absorption peak at $549 \mathrm{~nm}$ it is appropriate to use the $550 \mathrm{~nm}$ interference filter.

For primary standard we use pure $\mathrm{N}$-acetylneuraminic acid of human origin, extracted and purified in our laboratory (2).

For daily use as standards we take serum samples of low and high sialic acid content, which have been hydrolysed by the method used in the determination. These hydrolysed samples keep very well in the refrigerator for several months. Owing to the perfectly straight line relationship between optical densities and concentration, only two or three standards need be run every day.

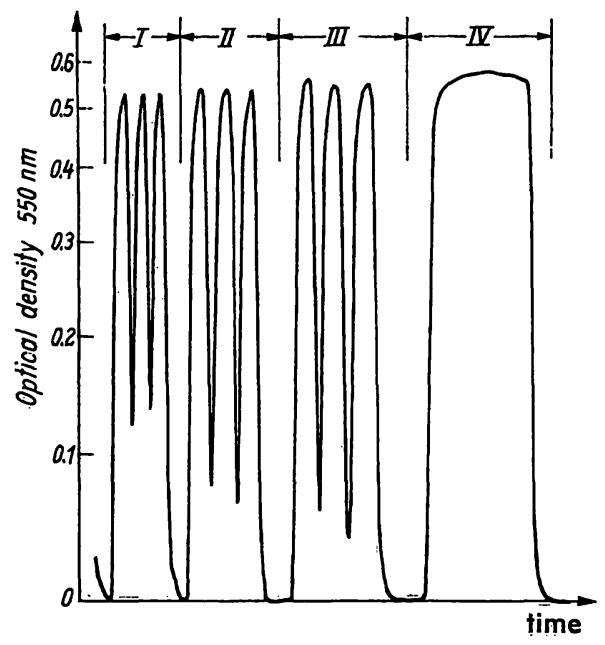

Fig. 2

Actual recording at 3 different speeds compared to continuous aspiration (Series B).

$I=60, I I=50, I I I=40$ determinations per hour; IV = continuous aspiration (5 minuts)

\section{Results and discussion}

With the proposed method 60 determinations of sialic acid can be run per hour. Figure 2 shows results obtained at the rate of 40,50 and 60 determinations per hour as compared with a five minute continuous sample aspiration. Even at maximum speed, the peak height reaches more than $90 \%$ of that with continuous aspi-

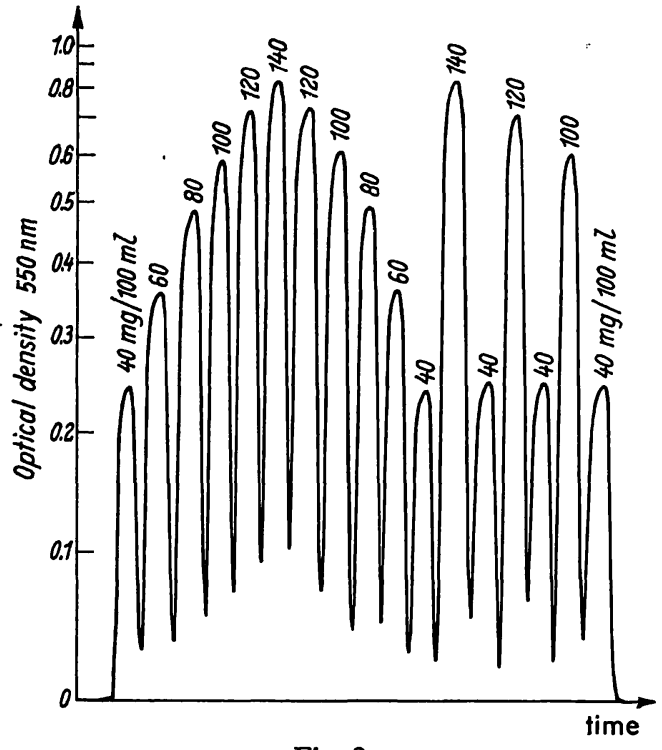

Fig. 3

Actual recording of standard solutions showing reproducibility and high-low sample interference (40 determinations per hour)

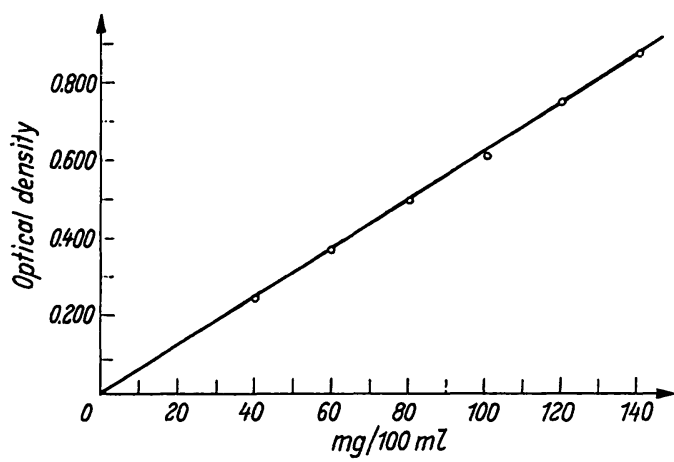

Fig. 4

Straight line relationship between optical density at $550 \mathrm{~nm}$ and concentration of sialic acid ( 60 determinations per hour)

ration. Results obtained with a series of standard solutions are shown in figure 3 . This same series serves to illustrate the reproducibility and the excellent sample separation. Figure 4 shows the perfect straight line relationship between optical densities and concentrations even at the speed of 60 determinations per hour. The mean error, calculated by analysing 9 serum samples in duplicate, is $2.2 \%$. By aspirating the same hydrolysed serum sample nine times, we arrived at a mean error of $1.1 \%$. As a further check on the method we analysed

Tab. 1

Comparison of the classical manual method of WARREN with the proposed automatic method.

\begin{tabular}{ccccc}
\hline Sample $\mathrm{n}^{\circ}$ & $\begin{array}{c}\text { Manual value Autoanalyzer } \\
\text { mg. per } 100 \mathrm{ml} \\
\text { value } \\
\text { mg. per } 100 \mathrm{ml} \text { mg. per } 100 \mathrm{ml}\end{array}$ & $\begin{array}{c}\text { Difference } \\
\% \text { total }\end{array}$ \\
\hline 1 & 58 & 63.25 & +5.25 & 7.5 \\
2 & 73 & 78.25 & +4.75 & 7.2 \\
3 & 84 & 90 & +6 & 7.2 \\
4 & 87 & 94.25 & +7.25 & 8.3 \\
5 & 86 & 92.25 & +6.25 & 7.2 \\
6 & 58 & 62.75 & +4.75 & 8.2 \\
7 & 72 & 84.6 & +12.6 & 17.2 \\
8 & 103.5 & 105.25 & +1.75 & 1.9 \\
9 & 59 & 61.75 & +2.75 & 4.7 \\
\hline
\end{tabular}

Mean difference in percent of total: 7.75 


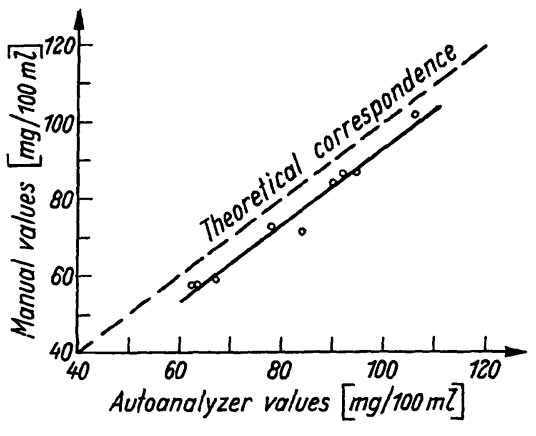

Fig. 5

Relation between manual and automatic values nine serum samples by both the classical manual method of WARREN and by the proposed automatic method. The results are shown in table 1 and figure 5 . As can be seen, the Autoanalyzer method gives consistantly higher results by about $8 \%$. This is most probably due to the incompleteness of the extraction of the coloured end product in the manual method.

Finally, we checked the effect of the most probable source of interference, namely the blood glucose. No interference could be detected by the addition of up to 10 times the normal amount of glucose.

This method has been in daily use in our laboratory for over a year and has been entirely satisfactory.

\title{
References
}

1. Ketelaer, $C_{H}$. J. und P. Delmotte, Acta neurol. psychiatr. Belg. 64, 441 (1964). - 2. BöнM, P., Dtsch. Zschr. Verdauungskrkh. 19, 65 (1959). - 3. Martensson, E., A. RAAL und L. Svennerholm, Biochim. biophysica Acta (Amsterdam) 30, 124 (1958). - 4. Svennerholm, L., Biochim. biophysica Acta
(Amsterdam) 24, 604 (1957). - 5. Mretrinen, T. und I. T. EAkKILuUkKainen, Acta chem. scand., 13, 856 (1959). - 6. WARren, L., J. biol. Chemistry 234, 1971 (1959). - 7. Courtors, J. E., Ann. biol. clin. (Paris) 21, 383 (1963). - 8. SAIfER, A. und S. Gertstenfeld, Clin. chim. Acta (Amsterdam) 7, 467 (1962).
P. Delmotte Melsbroek (Belgien) 16, tue van Heylen

\section{A Micromethod for the Routine Estimation of Inorganic Phosphate in Serum and Urine}

\author{
By A. J. Bastiaanse and C. A. M. Meijers \\ From the Clinical Laboratory, St. Anna Hospital (Direktor: Drs. C. A. M. Meijers) Geldrop, The Netherlands
}

(Eingegangen am 23. März 1967)

\begin{abstract}
A standard technique for the colorimetric determination of inorganic phosphate has been developed, based upon the work of ITAYA and UI, who found that Malachite Green at a low pH forms a complex with phosphomolybdate, which is measured at $660 \mathrm{~nm}$. The present method is different in that: 1. a lower concentration of Malachite Green is used, resulting in an analytically more suitable determination. 2. another stabilizing reagent is used. The present method has been applied to serum as well as urine.
\end{abstract}

Eine Standardmethode für die kolorimetrische Bestimmung von anorganischem Phosphat wird angegeben. Sie beruht auf der Arbeit von ITAYA und Ur, die fanden, daß Malachitgrün bei niedrigem pH einen Komplex mit Phosphomolybdat bildet, dessen Extinktion bei $660 \mathrm{~nm}$ gemessen wird. Die angegebene Methode unterscheidet sich von der von ITAYA und UI wie folgt: 1. Es wird eine geringere Malachitgrünkonzentration benutzt. Das ergibt eine analytische geeignetere Bestimmungsmethode. 2. Es wird ein anderes Stabilisierungsmittel vetwendet.

Die Methode kann zur Phosphatbestimmung in Serum und Harn angewandt werden.

Recently ITAYA and UI (1) introduced a new micromethod for the colorimetric determination of inorganic phosphate. Their procedure depends on the fact that Malachite Green at a low $\mathrm{pH}$ forms a complex with phosphomolybdate with a marked shift of the absorption spectrum. The colour developed is measured at $660 \mathrm{~nm}$. They reported determinations of percentage recovery with serum, and they compared the method with those of Fiske and Subbarow (2) and Martin and Doty (3), but only a few experimental figures were given.

In the present paper we have examined some aspects of the work of ITAYA and Ur. First we followed their standard procedure by pipetting $0.05 \mathrm{~m} /$ serum, standard or water into $4 \mathrm{~m} l 5 \%$ perchloric acid, adding $1 \mathrm{ml}$ of the centrifugate to $5 \mathrm{~m} l$ colour-developing reagent, immediately followed by $0.2 \mathrm{ml} 1.5 \%$ Tween 20 solution. The optical density was measured at $660 \mathrm{~nm}$ after $10 \mathrm{~min}$.

Later however, we modified their standard procedure by using a lower concentration of Malachite Green and a different stabilizing reagent. Our method gives precise and reproducible results when applied to serum as well as urine.

\section{Method}

Materials

Reagents

All reagents were analytical grade and included $\mathrm{KH}_{2} \mathrm{PO}_{4}$ (for the preparation of standards), $70 \%$ perchloric acid, $\left(\mathrm{NH}_{4}\right)_{6} \cdot \mathrm{MoO}_{24} \cdot$ - $4 \mathrm{H}_{2} \mathrm{O}$, Malachite Green and $37 \% \mathrm{HCl}$, all from Merck AG, Tween 20 (polyoxyethylene sorbitan monolaurate) from J. A. Boòm, 